\title{
Water status of two germinate Cenchrus ciliaris and Digitaria commutata indigenous endangered arid zone of Tunisia
}

\author{
Imen dhib *, Abedessalema bdessamad *, ksontini Mustapha *, Ali ferchichi ** \\ *National Institute for Research in Rural Engineering, Water and Forestry. \\ ** Institute of Arid Regions Médenine
}

\begin{abstract}
Cenchrus ciliaris is a fixing species on sandy soils. This is one of the most suitable species to maintain a high production at a time of year when the herd needs are high, and Digitaria commutata has significant production compared to other Poaceae.

Hawever, there is a degradation of graminaes plants in natural ecosystems in semi arid and arid area. This degradation has grown by lack of water and its loss through evapotranspiration exposing plants to water deficit. It is in this context stands our study : in which the whole work done stresses the point on the determination of the hydric statute in encounter of the luck of water in the two graminae (Cenchrus ciliaris and Digitaria commutata) indigenous dry land. The experimental tests are applied in a controlled environment (growth chamber) to INRGREF Tunis. The analyzes focus on adaptation to water stress at the physiological level made in C. ciliaris Matmata show a higher water stress at which the osmotic adjustment value is of the order of $2.19 \mathrm{MPa}$ the end of the $2^{\text {nd }}$ cycle of water stress sensitivity.

While Cenchrus ciliaris populations of Medenine, Jerba and the Digitaria commutate of Bouhedma show sensitivity to applied stress manifested by adjusting the order of -0.055 values -0.02 and -0.02 MPa, respectively, at the end of the second cycle of stress, regression of these two populations of species, may be due to the irregular and insufficient rainfall in recent years which prevents the increase in survival and development of plants
\end{abstract}

Keywords: Water Status / Poaceae / Threatened with extinction / arid area

\section{Introduction:}

The yearly and intra-yearly variability of rainfall (Alexander, 1989) and soil conditions and the biological stations may give great importance to differences in physiological behavior of plants : number of adaptive changes of order is recorded:

- Morphology: - Leaf curl in some grasses

- A reduction of surface evaporation

- An extension of the root system

- Physiological: - An accumulation of solutes (osmotic adjustment) for the plant to maintain turgor (Laffray, 1986)

To determine the plants potential osmotic modifications, we resort to the curve pression volume technic.

The two species studied (Cenchrus ciliaris and Digitaria commutata) are native to the arid regions of southern Tunisia in which the average rainfall was approximately $154 \mathrm{~mm}$ per year.

1. Plant materials:

\section{Material and Method}

The study was performed on seedlings of two indigenous Poaceae dryland Cenchrus ciliaris and Digitaria commutata 5 months old and from 3 study sites:

- Site Bouhedma: Region Sidi Bouzid (floor dry higher; variant mild winter; Mountain).

- Site Jerba: Region Medenine (lower floor hot arid winter Cote Sea).

- Site Matmata area Gabes (arid zone than mild winter; Mountain).

The experiment was conducted in semi-controlled nursery of INRGREF Ariana (semi-arid bioclimatic higher) conditions. Two water regimes were applied: control plants (NS) were watered daily and will stressed plants (S) underwent two cycles of 10 days drying by blackout separated by an intermediate rehydration watering. The choice of stations is based primarily on the availability of seeds, and their germination capacity. The substrate of breeding plants is characterized by moisture to the field capacity is about $26 \%$ and its texture is: table 1. 
Table 1: Characteristics of soil.

\begin{tabular}{|c|c|c|c|c|c|c|c|c|c|}
\hline Matiel & $\begin{array}{c}\text { Clay } \\
\%\end{array}$ & $\begin{array}{c}\text { Silt } \\
\%\end{array}$ & $\begin{array}{c}\text { Fine } \\
\text { sand } \\
\%\end{array}$ & $\begin{array}{c}\text { Coarce } \\
\text { sand } \%\end{array}$ & $\begin{array}{c}\text { Coarce } \\
\text { limestone } \\
\%\end{array}$ & $\begin{array}{c}\mathrm{MO} \\
(\mathrm{g})\end{array}$ & $\mathrm{PH}$ & $\mathrm{P}_{2} \mathrm{O}_{5}$ & $\mathrm{~K}_{2} \mathrm{O}$ \\
\hline & 12 & 12 & 30 & 43 & 3 & 3.2 & 7.5 & 4 & 0.17 \\
\hline
\end{tabular}

\section{Methodology:}

The osmotic potential of the vacuolar accumulation of solutes, its value is determined by the law of Van t Hoff $(\psi \mathrm{o}=-\pi)$. The water potential $(\psi \mathrm{h})$, osmotic $(\psi \mathrm{O})$ and turgor $(\psi \mathrm{t})$ are related by the following equation: $=\Psi \mathrm{h} \Psi \mathrm{o}+\Psi \mathrm{t}$ with $\Psi \mathrm{h}<\mathrm{or}=0 \Psi_{\mathrm{o}}<0$

$\Psi_{0}<0$

$\Psi \mathrm{t}>\mathrm{ou} 0$

During water stress the plant with a lowering of the osmotic potential in response to a loss of water and thus vacuolar solute concentration. Applying the relationship PV = constant, so was the technique of pressure volume curve: $\Psi_{0} \Psi_{0} \max =\mathrm{Vmax} * / \mathrm{V}$. So if the volume of water contained in the plant decreases, increases its osmotic potential is by simple effect of solute concentration. However, if the measured is less than the $\Psi_{0} \Psi_{0}$ calculated, there then has osmotic adjustment (net accumulation of solute) which allows the plant cells to maintain a positive turgor. It is therefore essential to use a technique in which $\Psi_{0}$ is measured for relative water content (RWC) defined either at full turgor or zero turgor (plasmolysis) when we want to analyze the responses of plants subjected to water stress. The technique of pressure volume curves allows this approach.

The relative water content (RWC) is the ratio of the water content of the sample taken from the maximum water content when the cells are full turgor. The value found is expressed in percent. The saturation time depends on the plant material used and its water status. RWC = PF-PS/Psat-PS * With 100 PF: Weight of fresh weight of the aerial part, PS: Psat dry matter Weight: Weight at full turgor

\subsection{Theoretical basis of the pressure volume curve:}

According to the relationship $\Psi \mathrm{h} \Psi \mathrm{o}+=\Psi \mathrm{t}, \Psi \mathrm{t}=0$ if we $\Psi \mathrm{h} \Psi \mathrm{o}$ gold $\Psi_{\mathrm{o}}=\mathrm{x} \mathrm{V}=$ constant so we can write $\mathrm{V}=$ constant $\mathrm{x} \Psi \mathrm{h}$ However $\mathrm{V}$ which represents the fraction of movable the water that is to say, the vacuolar volume is difficult to measure. It can thus replace the percentage of V RWC expressing contained in the water, which can be easily determined: where $\mathrm{x} \Psi \mathrm{h}$ RWC $=$ const Where the graphic representation $\Psi$ versus $1 / \mathrm{RWC}$.

The RWC reduction may be effected by extraction of the water due to the increased pressure in the pressure chamber Scholander increments of 2.5 Bars.

\subsection{Implementation of the technique:}

- Section in leaf water to avoid possible embolism

- Rehydration samples overnight in the dark in a laboratory environment

- After taring, we proceed to the bag sheet (to prevent water loss during the pressure-mounted) and determining its weight.

- Is the measurement $\Psi \mathrm{h}$ then up to 2.5 Bar pressure in the chamber and the sap that comes from the section is wiped, when the sap out more gently releases the pressure and leaves the sheet.

- Weigh the sheet.

- Measures was continued by increasing the pressure of 2.5 bars at each measurement up to 36 Bars

- The samples are placed in an oven at $80^{\circ} \mathrm{C}$ for 24 hours to obtain their dry weight.

- Measurements of parameters of the pressure volume curve were performed on 6 samples / population / treatment at the end of the first and second cycle of drought.

\subsection{Analysis of the pressure volume curve:}

From the representation $1 / \psi \mathrm{h}=\mathrm{f}(\mathrm{RWC} \%)$ we draw a pressure volume curve which shows the characteristics of a relationship of two parts: a curvilinear portion corresponds to potential positive turgor and at low water and a linear portion with zero potential of turgidity and water at elevated values. Extrapolation

- $1 / \psi \mathrm{h}=0$ gives no water is displaceable ie bound water (The water fraction appoplastique) membrane, etc... The walls extrapolation $\% \mathrm{RWC}=100$ us gives the value of the reverse osmotic potential at full turgor. ( $\Psi 100 \pi)$ - The osmotic potential at zero turgor $(\psi \pi 0)$ : It is estimated by projection on the y-axis of the point of intersection of the line with the Bend Kansas. This parameter is used to find the lower limit of the water potential at which the turgor potential may exist.

- The relative water content at zero turgor ( $\mathrm{RWC} 0$ ): The value is determined by projection on the $\mathrm{x}$-axis at the intersection of the straight line with the curve. 
- We can calculate the modulus of elasticity $\varepsilon$ defined by the following relationship: Nabil and Coudret, 1995): $(\varepsilon \max )=(\Psi \Pi 100-\Psi \Pi 0) \times(1$ - EL $) /(1$ - RWC 0$)$

- The Adjustment osmotic $\Delta \psi \mathrm{s} 100$ : Osmotic adjustment is determined indirectly from the pressure volume curve and is calculated from the difference between the osmotic potential at full turgor $\psi 100 \pi$ stressed and the controls.

The osmotic adjustment $=\psi \pi 100$ stressed $-\psi \pi 100$ witnesses

- Osmotic Adjustment for: It determines the degree of adjustment: $\mathrm{AOR}=(\Delta \Psi \pi 100 \mathrm{~S} / \Psi \pi 100 \mathrm{~T}) \times 100$.

\section{Physiological characterization:}

\section{Results and discussion:}

\subsection{To full turgor osmotic potential $(\psi 100 \pi)$ :}

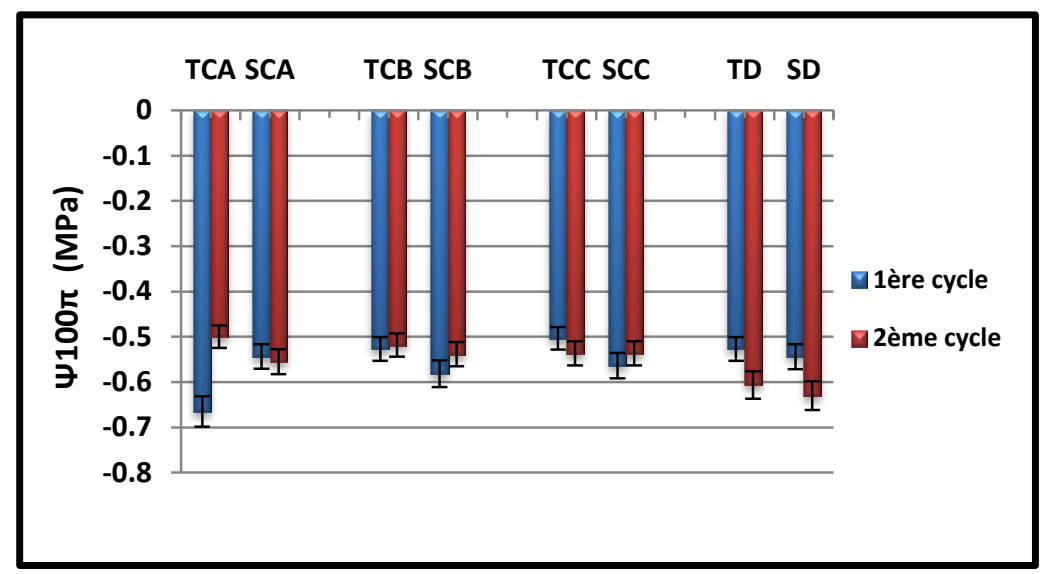

Figure 1: Variation of osmotic potential at full turgor in the control $(T)$ and stressed $(S)$ of: Cenchrus ciliaris: C; Medenine: A; Jerba: B; Matmata: C and Digitaria commutata: D of Bouhedma, during the two cycle water stress.

The values obtained are of the order of $-0.54,-0.58,-0.53$, and $-0.56 \mathrm{MPa}$ in stressed and $-0,67,-0.53,-0.53$ and $-0.50 \mathrm{MPa}$ for controls respectively for populations Medenine; Jerba, Matmata and Bouhedma at the end of the first cycle of drought. At the end of the second cycle of drought, the values are of the order of $-0.50,-0.52,-0.61$ and $-0.56 \mathrm{MPa}$ in stressed and $-0.56,-0,54,-0.63$ and $-0.54 \mathrm{MPa}$ in controls respectively for populations Medenine; Jerba, Matmata and Bouhedma (fig 1).

The highest values are recorded in the population of Jerba (-0.58 MPa) to a lesser degree among populations of Digitaria commutata of Bouhedma (-0.56 MPa), Cenchrus ciliaris, Medenine (-0.54 MPa) and minimum in the population of Matmata $(-0.53 \mathrm{MPa})$, at the end of the first cycle of drought. While at the end of the second cycle, the highest values are recorded in populations of Cenchrus ciliaris of Matmata (-0.61 MPa), to a lesser degree among populations of Digitaria commutate of Bouhedma (-0.56 MPa), Cenchrus ciliaris and minimum of Jerba in the populations Medenine (-0.50 MPa). (Fig 1)

\subsection{Osmotic potential at zero turgor $(\psi 0 \pi)$ :}




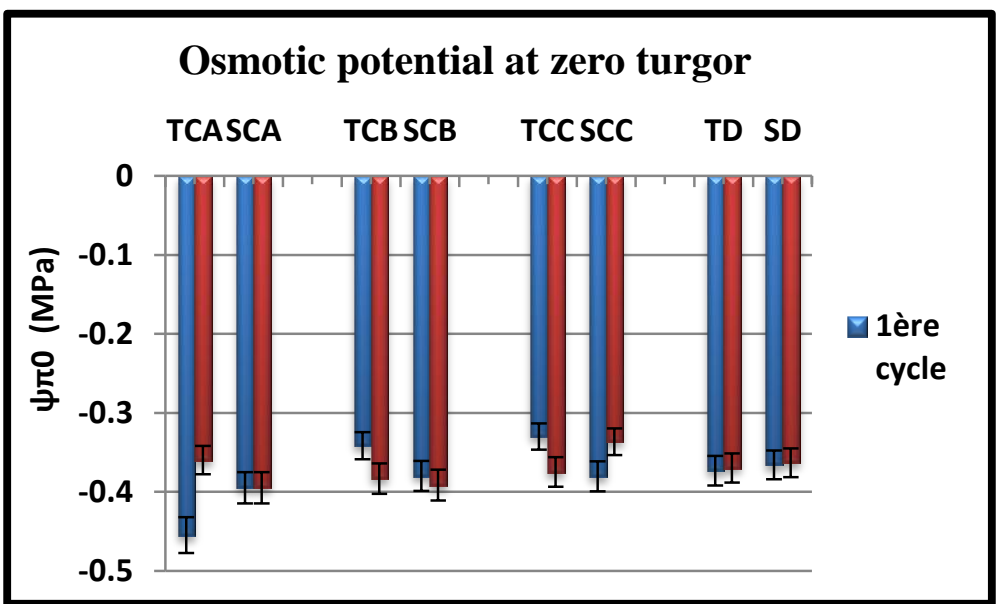

Figure 2: Variation of osmotic potential at zero turgor in the control (T) and stressed (S) of: Cenchrus ciliaris: C; Medenine: A; Jerba: B; Matmata: C and Digitaria commutata:D of Bouhedma, during the two cycle water stress.

The values are of the order of $-0.40,-0.38,-0.34$, and $-0.37 \mathrm{MPa}$ in stressed and $-0.40 ;-039,-0.63$ and -0.54 MPa for controls respectively for populations Medenine; Jerba, Matmata and Bouhedma at the end of the first cycle of drought.

At the end of the second cycle of drought, the values are of the order of $-0.36,-0.38,-0.37$ and $-0.38 \mathrm{MPa}$ in stressed and $-0.40,-0,39,-0.36$ and $-0.34 \mathrm{MPa}$ in controls respectively for populations Medenine; Jerba, Matmata and Bouhedma (fig 2). The highest values are recorded in the population of Medenine (-0.40 MPa) to a lesser degree among populations of Jerba (-0.38 MPa), Digitaria commutata of Bouhedma (-0.37 MPa) and minimum in the population of Matmata (-0.34 MPa), at the end of the first cycle of drought. While at the end of the second cycle, the highest values are recorded in populations of Jerba and Bouhedma (-0.38 MPa). To a lesser degree among populations Matmata (-0.37 MPa) and lowest in population Medenine (-0.36 MPa). (Fig 2).

\subsection{Osmotic Amplitude:}

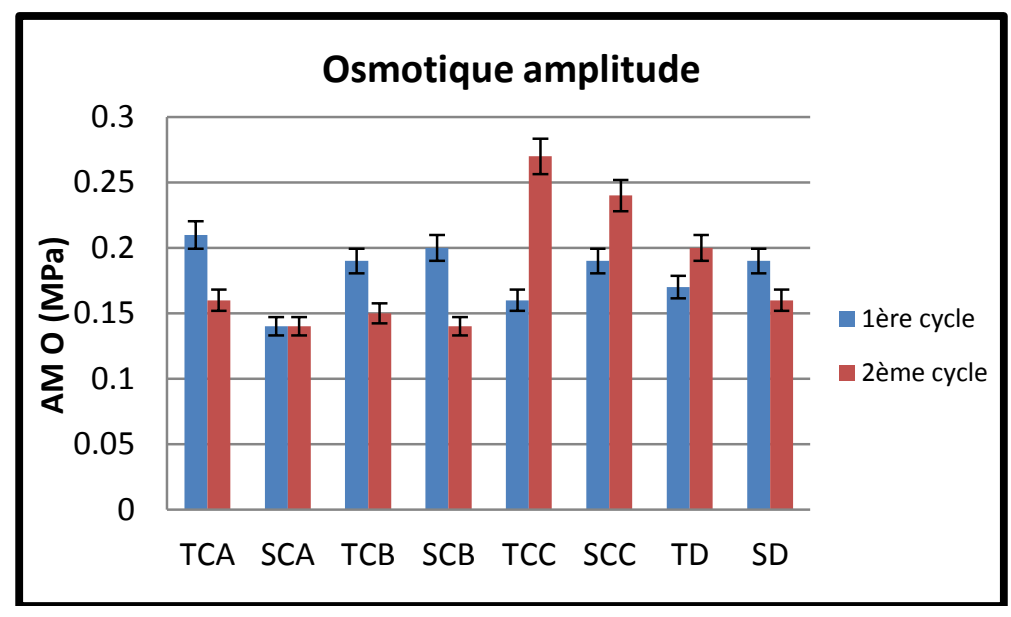

Figure 3: Variation of osmotique amplitude in the control $(\mathrm{T})$ and stressed $(\mathrm{S})$ of: Cenchrus ciliaris: $\mathrm{C}$; Medenine: A; Jerba: B; Matmata: C and Digitaria commutata: D of Bouhedma, during the two cycle water stress.

The values are in the order of $0.14,0.2,0.19$, and $0.19 \mathrm{MPa}$ in stressed and $0.21,0.19,0.16$ and $0.17 \mathrm{MPa}$ for witnesses respectively populations Medenine; Jerba, Matmata and Bouhedma at the end of the first cycle of drought. At the end of the second cycle of drought, the values are of the order of $0.14,0.14,0.24$ and $0.16 \mathrm{MPa}$ in stressed and $0.16,0.15,0.27$ and $0.2 \mathrm{MPa}$ in controls respectively for populations Medenine; Jerba, Matmata and Bouhedma (fig 3). The highest values are recorded in the population of Medenine (0.21 MPa) to a lesser degree among populations of Jerba $(0.19 \mathrm{MPa})$, Digitaria commutata $(0.17 \mathrm{MPa})$, and minimum in the population of Matmata $(0.16 \mathrm{MPa})$ at the end of the first cycle of drought. While at the end of the second cycle, 
the highest values are recorded in the population of Matmata $(0.24 \mathrm{MPa})$ to a lesser degree among populations Bouhedma (0.16 MPa) and lowest among populations Medenine and Jerba (0.14 MPa) (Fig. 3).

\subsection{Osmotic adjustment:}

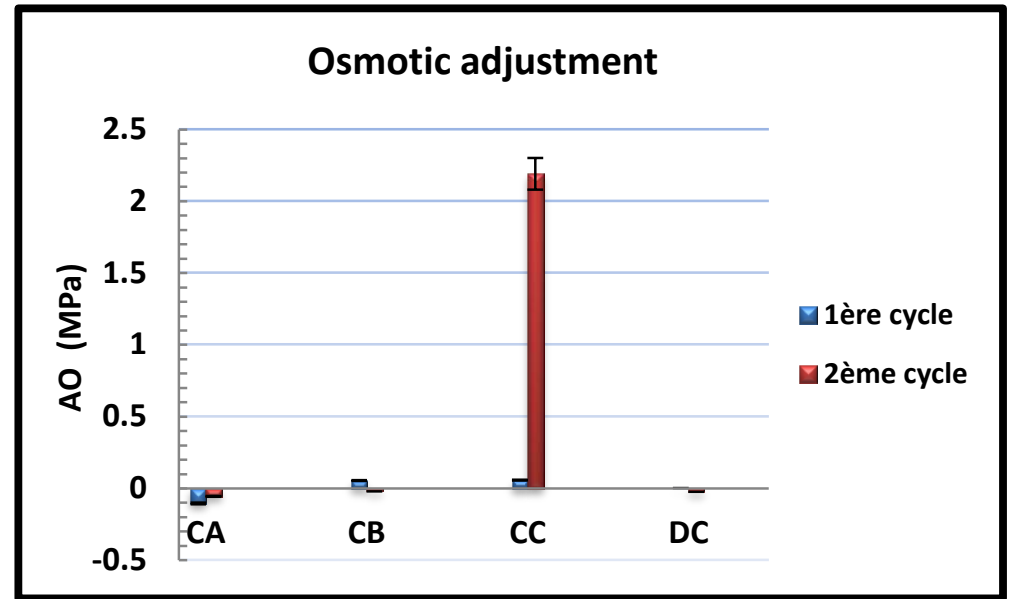

Figure 4: Variation of osmotic adjustment in the control (T) and stressed (S) of: Cenchrus ciliaris: $C$; Medenine: A; Jerba: B; Matmata: C and Digitaria commutata: D of Bouhedma, during the two cycle water stress.

The values are of the order of $-0.105,-0.55,-0.058$, and $-0.003 \mathrm{MPa}$ respectively for populations Medenine; Jerba, Matmata and Bouhedma at the end of the first cycle of drought. At the end of the second cycle of drought, the values are in the range of $-0.0055,-0.02,2.19$ and $-0.02 \mathrm{MPa}$ respectively for populations Medenine; Jerba, Matmata and Bouhedma (fig : 4). The most important values are stored in the Cenchrus ciliaris population Medenine (-0.105 MPa), to a lesser extent in the population of Jerba (-0.55 MPa) and Matmata (-0.058 MPa) compared with Digitaria commutata of Bouhedma ( $-0.03 \mathrm{MPa})$ at the end of the first cycle. At the end of the second cycle, the most important value is stored in the population of Matmata (2.19 MPa), negative in the population of Medenine (-0.055 MPa) and a lower value in the population and the population of Jerba Digitaria commutata of Bouhedma (-0,02MPa) (Fig: 4).

\subsection{On osmotic adjustment relative:}

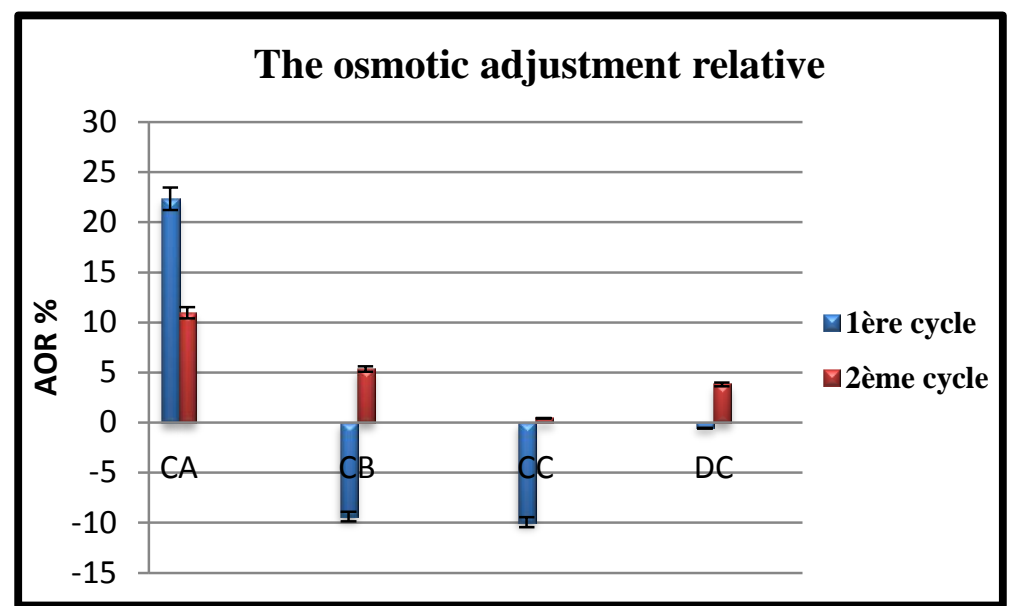

Figure 5: Variation of the osmotic adjustment relative in the control (T) and stressed (S) of: Cenchrus ciliaris:C; Medenine:A; Jerba:B; Matmata:C and Digitaria commutata:D of Bouhedma, during the two cycle water stress. 
The values are of the order of $0.8,1.09,1$, and $1.12 \mathrm{MPa}$, respectively, for populations Medenine; Jerba, Matmata and Bouhedma at the end of the first cycle of drought. At the end of the second cycle of drought, the values are of the order of 0.89, 0.96, 0.96 and $0.1 \mathrm{MPa}$, respectively, for populations Medenine; Jerba, Matmata and Bouhedma (fig: 5). The most important values are stored in the populations (1.12 MPa), to a lesser extent in populations of Jerba $(1.09 \mathrm{MPa})$ compared to Matmata $(1 \mathrm{MPa})$ Medenine $(0.8 \mathrm{MPa})$ at the end of the first cycle. At the end of the second cycle, the most important value is stored in the population of Digitaria commutata Bouhedma (1 MPa), to a lesser extent in populations of Jerba; Matmata (0.96 MPa) and lowest among those of Medenine (0.89MPa) (Fig: 5).

\subsection{Relative water content at zero turgor (RWC0):}

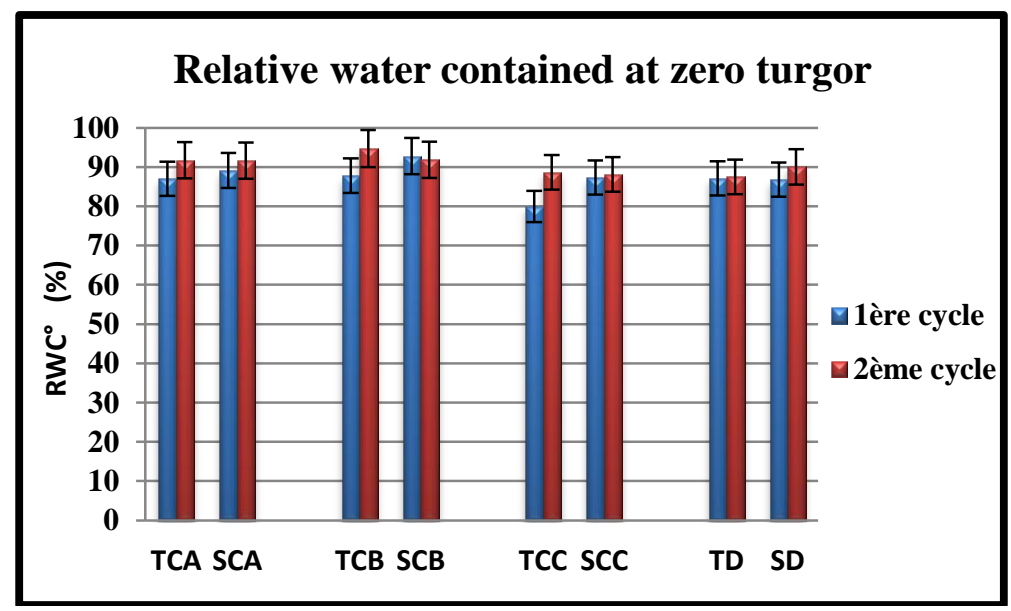

Figure 6: Variation of relative water contained at zero turgor in the control (T) and stressed (S) of: Cenchrus ciliaris: C; Medenine: A; Jerba: B; Matmata: C and Digitaria commutata: D of Bouhedma, during the two cycle water stress.

The values are of the order of $89.17,92.80,92.17$, and $89.17 \%$ in stressed and $87.04,87.77,8708$ and $79.92 \%$ for controls respectively for populations Medenine; Jerba, Matmata and Bouhedma at the end of the first cycle of drought. At the end of the second cycle of drought, the values are of the order of 91.74, 94.70, 87.50 and $88.67 \%$ in stressed and 91.63, 91.83, 90, 88, 11\% in controls respectively for populations Medenine; Jerba, Matmata and Bouhedma (Fig. 6). The highest values are recorded in the population of Jerba (92.80\%), to a lesser degree among populations Matmata (92.17\%) and lowest among populations of Digitaria commutata Bouhedma and the Medenine $(89,17 \%)$, at the end of the first cycle of drought. While at the end of the second cycle, the highest values are recorded in populations of Jerba $(94.70 \%)$, to a lesser degree among populations Medenine (91.74\%) and lowest among populations Digitaria commutata of Bouhedma (88.67\%) and Cenchru sciliaris Matmata (87.50\%) (Fig: 6).

\subsection{Water fraction appoplastique: bound water (EL):}

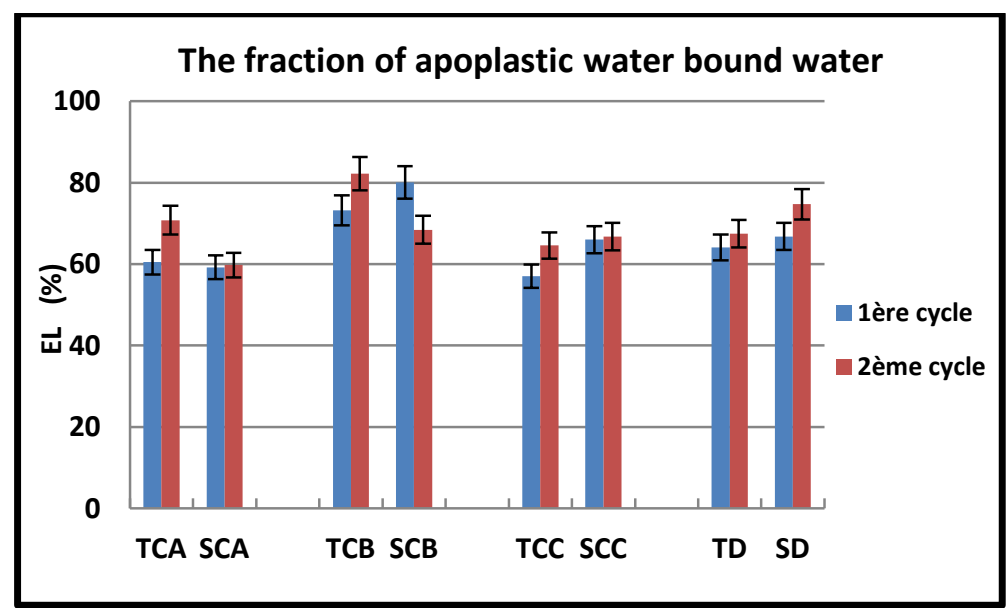


Figure 7: Variation of the fraction of apoplastic water bound water in the control $(T)$ and stressed $(S)$ of: Cenchrus ciliaris: C; Medenine: A; Jerba: B; Matmata: C and Digitaria commutata: D of Bouhedma, during the two cycle water stress.

The values are of the order of 59.22, 80.04, 77.32, 68.64\% in stressed and $60.48,73.20,64.07,57.06 \%$ for controls respectively for populations Medenine; Jerba, Matmata and Bouhedma at the end of the first cycle of drought. At the end of the second cycle of drought, the values are of the order of 70.79, 82.20, 67.45, 64.57\% in stressed and 59.75, 68.43, 74.71 and 66.76\% respectively in the control populations Medenine; Jerba, Matmata and Bouhedma (Fig: 7). The water-related value is the highest recorded in the population of Cenchrus ciliarisJerba Medenine (80.04\%) to a lesser degree among populations Matmata (77.32\%), Digitaria commutata of Bouhedma (68.64\%) and lowest among those of Medenine $(59.22 \%)$ at the end of the first cycle of drought.

While at the end of the second cycle, the highest value recorded in the population of Jerba (82.20\%), to a lesser extent in the population of Medenine $(70.79 \%)$ and lowest in the population Matmata $(67.45 \%)$ and Digitariacommutata (64.57). (Fig: 7).

\subsection{Bulk modulus of elasticity ( $(\max )$ :}

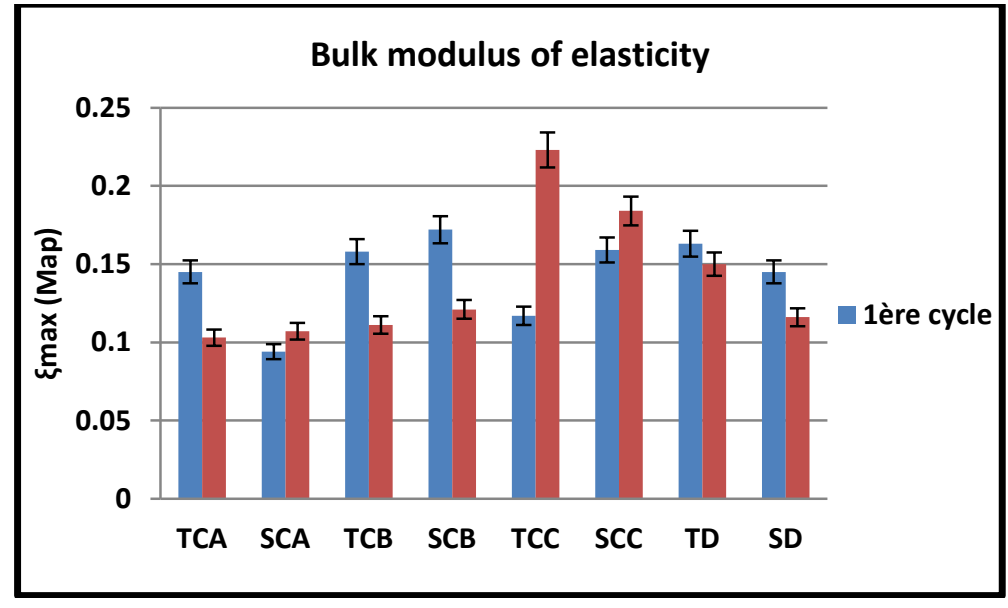

Figure 8: Variation of bulk modulus of elasticity in the control (T) and stressed ( $S$ ) of: Cenchrus ciliaris: C; Medenine: A; Jerba: B; Matmata: C and Digitaria commutata: D of Bouhedma, during the two cycle water stress.

The values are of the order of $0.094,0.172,0.159,0.145 \mathrm{MPa}$ in stressed and $0.145,0.158,0.117$ and 0.163 MPa for controls respectively for populations Medenine; Jerba; Matmata of Bouhedma and at the end of the first cycle of drought. At the end of the second cycle of drought, the values are of the order of 0.107, 0.121, 0.184 and $0.116 \mathrm{MPa}$ in stressed and $0.103,0.111,0.223$ and $0.15 \mathrm{MPa}$ in the controls respectively for populations Medenine; Jerba , Matmata and Bouhedma (Fig: 8). The highest values are recorded in the population of Jerba $(0.172 \mathrm{MPa})$ to a lesser degree among populations Matmata (0.159 MPa), Digitaria commutata of Bouhedma $(0.145 \mathrm{MPa})$ and minimum in the population of Medenine $(0.145 \mathrm{MPa})$ at the end of the first cycle of drought.

While at the end of the second cycle, the highest values are recorded in the population and Matmata $(0.184$ $\mathrm{MPa})$, to a lesser extent in the population of Jerba $(0.121 \mathrm{MPa})$ and lowest among those of Bouhedma (0.116MPa) and Medenine (0.107 MPa). (Fig: 8).

\section{Statistical analysis:}

Statistical analyzes were performed by SPSS 20 software. For the first cycle of water stress, the Duncan test at $5 \%$ indicates no difference between the populations for the osmotic potential at full turgor parameter, and contained the same relative water, whereas the osmotic potential zero turgor test discriminates two groups: group A (Cenchrus ciliaris Medenine, Cenchrus ciliaris Jerba and Digitaria commutata of Bouhedma.), group B (Cenchrus ciliaris Jerba Digitaria commutata Cenchrus ciliaris of Bouhedma.) and group AB (Cenchrus ciliaris Jerba and Digitariacommutata of Bouhedma). 
As well as bound water on two groups: A (Cenchrus ciliaris Medenine of Digitaria commutata Bouhedma and Cenchrus ciliaris of Matmata), B (Digitaria commutata of Bouhedma, Cenchrus ciliaris of Matmata and Cenchrus ciliaris of Jerba) and AB (Digitaria commutata of Bouhedma and Cenchrus ciliaris of Matmata).

There are two groups for osmotic adjustment parameter A (Cenchrus ciliaris of Medenine) B (Digitaria commutata of Bouhedma, Cenchrus ciliaris of Jerba and Cenchrus ciliaris of Matmata), two groups as for the character of osmotic adjustment on A (Digitaria commutata of Bouhedma, Cenchrus ciliaris of Jerba and Cenchrus ciliaris Matmata) B (Cenchrus ciliaris of Medenine).

For the second cycle of water stress, the Duncan test at $5 \%$ discriminates two homogeneous groups for the full turgor osmotic potential A (Digitaria commutata of Bouhedma) and B (Cenchrus ciliaris of Matmata. Cenchrus ciliaris of Jerba and Cenchrus ciliaris Medenine), while for the zero potential osmotic turgor and tonicity adjustment there not significantly difference between the populations.

Whereas analyzes discriminate three different groups contained on the water A (Digitaria commutata of Bouhedma and Cenchrus ciliaris of Matmata) B (Cenchrus ciliaris of Medenine), C (Cenchrus ciliaris of Medenine, Cenchrus ciliaris of Jerba) and BC (Cenchrus ciliaris of Medenine) to bound water, there are three homogeneous groups significantly different A (Cenchrus ciliaris of Matmata, Digitaria commutata of Bouhedma and Cenchrus ciliaris of Medenine) B (Cenchrus ciliaris of Medenine and Cenchrus ciliaris of Jerba) AB (Cenchrus ciliaris Medenine) the same for osmotic adjustment for one to three significantly different groups are A (Digitaria commutata of Bouhedma. Cenchrus ciliaris of Jerba and Cenchrus ciliaris of Matmata) B (Cenchrus ciliaris of Matmata, Cenchrus ciliaris of Medenine) and AB (Cenchrus ciliaris of Matmata) for stressed plants during the second cycle at $5 \%$.

\section{Discussion:}

Plant growth depends on their ability to maintain a positive turgor. This process is the main physiological adaptation to water deficit form (Henchi, 1987). Many studies have been devoted to the study of a set of parameters describing the water relations of the plants (Stoker, 1929, Ritchie 1985; Henchi 1987; Rejeb1992; Ksontini, 1996). The results of Figure 6 show turgor loss of relative contained in water equal to or greater than $87 \%$ in different stressed plants after the first and second cycle of applied stress, for Cenchrus ciliaris Digitaria commutata

a reduction of $3 \%$ for the population of Cenchrus ciliaris of Jerba, $0.5 \%$ and $0.1 \%$ for the population of Cenchrus ciliaris of Matmata and the Medenine, and an increase of about $2.5 \%$ population of Digitaria commutata of Bouhedma. In any case of plants, the reduction due to lack of water in the relative water content for the loss of turgor is not important according Henchi 1986 different populations maintain a high water content even in adverse water conditions. According to Henchi 1986, the results of the amplitude of the observed variation cannot explain the existence of these species in semi-arid to arid climate and does not qualify these plants as plants that can withstand dehydration.

On the other hand, we find that the osmotic potential at full turgor does not vary significantly, in fact, among the population of Cenchrus ciliaris of Medenine, osmotic potential at full turgor is $-0.5 \mathrm{MPa}$ at the end of the second cycle of stress for witnesses and $-0.55 \mathrm{MPa}$ at the end of the second cycle of stress for stressed plants, a decrease of $-0.05 \mathrm{MPa}$ as a result of drought. Among the population of Cenchrus ciliaris of Jerba, osmotic potential at full turgor was $-0.51 \mathrm{MPa}$ for witnesses plants due to drought and $-0.53 \mathrm{MPa}$ in stressed plants at the end of the second cycle stress is a reduction of $-0.02 \mathrm{MPa}$ as a result of drought.

Among the population of Cenchrus ciliaris of Matmata, there is no difference between the stressed and witnesses. Among the population of Digitaria commutata, osmotic potential at full turgor is of the order of -0.60 $\mathrm{MPa}$ in witnesses of the second cycle of stress plants and $-0.63 \mathrm{MPa}$ in stressed plants at the end of the second cycle of stress either lowering $-0.03 \mathrm{MPa}$ as a result of drought. This reduction is not important in the different populations studied, and it does not explain the observed resistance. Similarly osmotic potential to zero turgor exhibits neither notable variation between the treated and witnesses' plants nor a significant difference between the various populations.

To better study the osmotic changes during the drought time, we have shown the variation of the difference in osmotic potential at full turgor measurements between the witnesses and dry plants according to the drying time (Fig. 4), such a procedure is a direct measure of the degree of osmotic adjustment. The results obtained show that the dried samples show a low capacity of osmotic adjustment. It was not until the end of the second cycle of drought that the difference in osmotic potential between witnesses and dehydrated reached more than 2.2 MPa for the population of Cenchrus ciliaris of Matmata. Comparison of the relative osmotic adjustment in different populations studied with other capacities found; as Plantago albican between 25 and 28\% (Henchi, 1986) compared the ability of adjustment relative osmotic obtained by Jones and Turner, 1978 at Sorghum and Morgan 1977 in Triticum dicocum which are respectively about 129 and 100\%, the values of the capacity of osmotic adjustment received are relatively low, in fact, it is of the order of $22 \%$ for Cenchrus ciliaris 
of Medenie , 5\% for Cenchrus ciliaris of Jerba, $1 \%$ for Cenchrus ciliaris Matmata and 4\% of Digitaria commutata Bouhedma.

So the accumulation of solutes responsible for osmotic adjustment is not significant and confirms the previous results. In fact, the presence of an osmotic reduced adjustment associated with low accumulation of organic solutes as well as maintaining a high water content at zero turgor does not explain the presence of this species in different bioclimatic zones ranging from semi-arid to arid and prevent thinking about drought resistance by mere tolerance to dehydration, since osmotic adjustment is considered as a criterion for drought tolerance, it allows the maintenance of turgor compatible with physiological activities in limiting water conditions, as well (Cutler 1980; Chimenti 2002)

The elastic properties of the walls allow plants undergoing dehydration under the effect of water deficit to avoid damage caused by internal mechanical pressure on the wall. Similar results have been reported in sunflower (Chimenti et al., 1994) and white fir (Marshall et al., 1999). Increasing modulus of elasticity (e) in the stressed plants is due to a wall lignifications dehydrated tissues making them less elastic. And increasing the elasticity of the cell wall cannot be held to explain the maintenance of turgor observed in different treatments to low water potentials. Furthermore, the water content of the appoplasme (AWC) significantly decreases a water regime to another and, thereby, cannot explain the maintenance of this turgor. It is likely that different populations maintain a positive turgor under water stress, through an active accumulation of solutes.

It, therefore, seems difficult to differentiate the populations studied by this technique, it is likely that resistance to drought is associated with the establishment of several mechanisms and that osmotic adjustment would only be one aspect.

In conclusion, after the various analyzes, we can classify the population of Cenchrus ciliaris Matmata more resistant to drought by its most important osmotic adjustment value, then followed by that of Jerba population of Digitaria commutata of Bouhedma and Cenchrus ciliaris population Mednine.

\section{References}

[1] Albouchi A., Sebei H. Mezni M.Y. et El Aouini M.H. 2000.- influence de la durée d'une alimentation hydrique déficit sur la production de biomasse, la surface transpirante et la densité stomatique d'Acacia cyanophyllaLindl. Ann INRGREF Tunis 4 : 138161

[2] Alexandre DY. 1989.-Pluies et alimentation en eau des plantes dans la région de Sinnamary (Guyane francaise).Nature guyanaise $3,28-36$

[3] Bejaoui Z., AlbouchiA., Abassi M., Lamhamdi M.S., El Aouni M.H., 2008 .-Actes scientifique de 1'INRGREF Hammamet 1113 Novembre 2008 La biodiversité dans les aires protégés.686-708.

[4] Bejaoui Z.,Albouchi A. ,Lamhamdi M.S. et El Aouni M.H. 2008 .- Effet d'un assèchement édaphique sur la croissance, l'allocation de biomasse et les relations hydrique chez casuarina glauca. Botanique 86 1242- $1251 ; 2008$

[5] Chimenti CA, Hall AJ. 1994. - Responses to water stress of apoplastic water fraction and bulk modulus of elasticity in sunflower (Helianthus annuus L.) genotypes of contrasting capacity for adjustment. Plant Soil; 166:101-7.

[6] Chimenti CA, Pearson J, Hall A. 2002. - Osmotic adjustment and yield maintenance under drought in sunflower. Field Crop Res; 10: $235-46$.

[7] Cutler JM, Shahan KW, Steponkus PL. 1980. - Alteration of internal water relations of rice in responses to drought hardening Crop Sci; 20: 307-18.

[8] Ennageh A. 2004.- Influence des conditions d'échantillonnage sur les paramètres hydriques déterminés par la technique des courbes pressions volume. Master.FST $106 \mathrm{p}$

[9] Henchi B. 1987.- Effet des contraintes hydriques sur l'écologie et l'écophysiologie de Plantagoalbicans L. Thèse de doctorat en sciences naturelles U. de Tunis.

[10] Jones M.M. ET N.C. Turner 1978.-Osmotic adjustment in leaves of sorghum in response to water deficits plant physio 60, 122126.

[11] Ksontini M., 1996.- Etudes écophysiologique des réponses à la contrainte hydrique du chêne liège (Quercus suber) dans le NordTunisie: Comparaison entre le chêne Kermès (Quercuscoccifera) et le chêne Zeen (Quercus faginea), Thèse docteur de l'université, $157 \mathrm{p}$.

[12] Henchi B. LougeutP.Vieira da silva J.B. 1986.- Evitement ou tolérance dans l'adaptation à l'aridité du plantain blanchatre : PlantagoalbicansspalbicanL.colloque sur les végétaux en milieu aride p.41-53.

[13] Laffray D., SaintiguilyA.,andLouguet P.1986.- Etude comparative des effets d'une contrainte hydrique progressive sur les paramètres hydriques de trois variétés de mil. Laboratoire de physiologie végétale, UFR Sciences et technologie Université Paris Val de Marne, F-94010 CRETEIL.

[14] Lilia Loussaief, Majid Mezni, Samira AschiSmiti 2009.- Stress hydrique de deux cultuvard de luzerne pérennes (Médicagosativa L.) Gabes et aquarius ; Science et changement planétaire, secheresse, volume 20, Numéro 3,303-11Juillet Aout Septembre 2009, Article de recherche.

[15] Marshall JG, Dumbroff EB. 1999. - Turgor regulation via cell wall adjustment in white spruce. Plant Physiology; 119: 313-9.

[16] Morgan J. M, 1977.- Differences in osmoregulation between wheat genotypes nature, 270, 234-235

[17] Nabil M., et Coudret A. 1995.- Effects of sodium chloride on growth tissue elasticity and solute adjustment in two: Acacia niloticasubspecies.Physiol plant. 93. 217-224.doi: 10.1111/j 1399-3054.1995tb 0222 o.x.

[18] Rejeb M.N. 1992.- Etudes des mécanismes de résistance à la sècheresse du caroubier (Ceratoniasiliqua L.) en Tunisie. Thèse, Université de Tunis, Faculté des sciences de Tunis.pp.199.

[19] Ritcher G.A. and Roden J.R. 1985. -Comparaison between two methods of generating pressure-volume curve.Plant Cell Env., 8, 49-53.

[20] Stoker O. 1929. - Eine Feld Method ZinBestiminug der momentanene transpiration and evaporation agrosse.Berdeutsch Bot Ger. 47, 126p. 